\section{Opacity of financial information, adoption of international standards and legal origins}

\author{
Renata Turola Takamatsu \\ Universidade Federal de Minas Gerais (UFMG), Faculty of Economics, \\ Department of Accounting, Belo Horizonte, Brazil \\ Luiz Paulo Lopes Fávero \\ Universidade de São Paulo (USP), School of Economics, Business \\ and Accounting, São Paulo, Brazil
}

Received on

04/28/2016

Approved on

$04 / 19 / 2017$

\section{Responsible editor:}

Prof. Dr. Ivam Ricardo Peleias

Evaluation process:

Double Blind Review

\begin{abstract}
Purpose - The goal of this study was to investigate the relationship between the level of Earnings Opacity and a company's informational environment, specifically considering accounting standards and the legal origins of the system.
\end{abstract}

Design/methodology/approach - The sample consisted of publicly traded companies from 20 countries classified as emerging, based on agency Standard \& Poor's index. The sample included data from 2004 to 2013. In order to compare the indicators among the group of countries, taking into account their institutional characteristics, the Mann-Whitney test and the Kruskal-Wallis test were performed.

Findings - The assessment of the informational environment measures' behavior in emerging countries revealed that these measures were correlated, suggesting that, despite different behaviors, opacity proxies share information. The fact that earnings opacity was lower in countries that had already adopted international standards during the analyzed period was also observed. In the same sense, a higher level of income smoothing was detected in countries of French code law origins.

Originality/value - This article contributes to the understanding of the relationship between the characteristics of an accounting informational environment and the levels of opacity of the information emitted by accounting. Thus, this article has helped managers, investors and regulators to understand users' needs and how country-specific characteristics change their perspectives.

Keywords - Emerging markets; international standards; legal origins; earnings opacity.

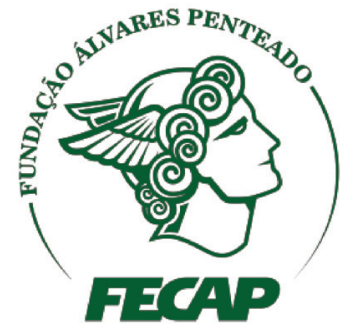

Review of Business Management

DOI: $10.7819 /$ rbgn.v0i0.3124 


\section{Introduction}

Financial reports issued by publicly traded companies play a crucial operational role in capital markets (Healy \& Palepu, 2001). Compulsory facing regulatory entities' requirements, these documents aim to mitigate the information asymmetry that persists between managers and investors outside the firm. Those who possess substantial knowledge regarding the profitability and continuity capabilities (agents) are specifically responsible for directing entities' activities. On the other hand, stakeholders depend on the dissemination of this knowledge to be able to allocate their scarce resources efficiently (Fatma \& Abdelwahed, 2010).

Regarding financial reports' ability to provide the required information, it is a known fact that, when referring to the capital market, accounting data is capable of changing the amount and variability of asset prices at the time of disclosure (Kothari, 2001). Traditional studies have focused their efforts on evaluating the relationship between the characteristics of the information disclosed and market variables at the level of each country, especially in developed capital markets. Since the theoretical assumptions about the relationship between the information disclosed by the companies and their characteristics may differ among countries, generalization of the results when they are confronted with samples composed of firms from different countries was impossible (Dong \& Stettler, 2011).

Bhattacharya, Daouk, and Welker (2003) point out that the differences that occur among countries' stock markets vary in terms of a number of characteristics, such as economic, political and legal infrastructure. To these authors, these phenomena exert a strong influence on the capital market as to how accounting figures are used and interpreted. A growing body of researchers has focused on how the particularities of each country and their respective capital markets generate differences in the content and timing of financial statements.
Literature on corporate finance shows that the choice of shares or contracts between firm and investors largely depends on the information available to investors. Investors' ability to protect their investments depends on both financial and legal institutions (Li \& Sullivan, 2015). In general terms, comparative empirical studies among companies from different countries have shown considerable differences in legal structure, enforcement mechanisms and corporate governance.

Accounting information is influenced by the environment it is produced in; it is the result of a range of interactions among factors such as: managers' motivation, accounting standards and institutions' enforcement (Bhattacharya et al., 2003). Studies such as La Porta, Lopez-deSilanes, Shleifer, and Vishny $(1997,1998)$ were able to demonstrate that laws and regulations that protect shareholders vary systematically across traditions and origins, interfering in a firm's internal agents capacity to limit the extent of investors' expropriation. In another aspect, Barth, Landsman, and Lang (2008) presented evidence of the influence of accounting standards on the quality of financial reporting. The authors' research showed that applying international accounting standards reduced companies' earnings management level.

Based on the considerations presented here, we can suppose that there is a relationship between institutional factors and the informational environment and the level of opacity of the information that companies report. Therefore, the following research question guides this study:

What is the relationship between the level of Earnings Opacity and a country's informational environment?

After characterizing the problem situation and defining the research question, the goal of this research can be established as: to investigate the relationship between the level of earnings opacity (measured by country-level measures of Income smoothing, loss aversion and earnings aggressiveness) and a company's informational 
environment (taking into consideration the accounting standards and the legal origins of the system).

To achieve the main goal, the study will cover the following specific objectives:

a) assess the different existing approaches to measure accounting earnings opacity;

b) infer about the influence of legal origins and financial standards on accounting earnings opacity;

c) detect possible differences among countries concerning the analyzed measures.

Despite the literature that has evolved in developed markets, there is still little explanation about the relationship between institutional factors and the informational environment in emerging markets. Emerging markets are known to present more serious problems of information asymmetry than developed countries. Thus, information disclosure would be more opaque. In addition, weak investor protection could reduce the effectiveness of disclosure of high quality information in interfering with the perceptions of its users. This would happen because financial reporting in emerging markets would be prone to a greater degree of manipulation in the face of low legal enforcement and, therefore, investors would not lean on the disclosed information (Fatma $\&$ Abdelwahed, 2010).

The results presented in this paper help investors to understand how aspects of the capital market actively generate differences in the usefulness of financial statements. Based on this information, investors can understand how the markets they participate in operate, and understand how characteristics of these markets affect financial statements, resulting in more conscious decision making.

To regulators, this paper suggests efforts to increase transparency and reduce the opacity of the accounting information provided. Regulators establish the rules with which firms report financial earnings to investors, creditors and other external parties. That is, they are responsible for developing standards to meet the needs of the various users of the financial statements. Thus, such as in a feedback loop, academic research elicits insights into what information these parties demand and how regulatory changes alter users' perspectives (Barth, Beaver \& Landsman, 2001).

\section{Literature review}

In this section, we present aspects that are inherent to the qualitative differences in the reporting of financial information among countries. Next, the characteristics of the informational environment in the countries included in this study were discussed (that is, legal origins and adoption of the international standards) and how these characteristics affect the quality and relevance of accounting information.

\section{I Differences in the quality of financial reporting among countries}

The differences among countries in the content and timing of corporate financial reporting cover several aspects. Thus, empirical studies have evaluated the differences in financial disclosure among countries, in the factors that explain such differences and, finally, in the relevance of the financial statements disclosed (Foster, Kasznik \& Sidhu, 2012). In this sense, a systematic and substantial variation in the influence of financial reporting among countries has been documented. French and Poterba (1991) examined how differences in accounting result in differences in the earnings per share index. Specifically, these authors compared the results found in the United States and Japan. They point out that approximately $50 \%$ of the disparity comes from differences in accounting practices.

Leuz, Nanda, and Wysocki (2003) evaluated the practice of earnings management, also analyzing the systematic differences among the 31 countries in the sample. In their findings, an endogenous link could be identified between corporate governance and the quality of reported earnings. That is, firms present in countries with a developed stock market, dispersed property structure, strong investor rights and high legal 
enforcement tend to present a lower level of earnings management.

Ali and Hwang (2000) argued in the same sense. Based on data from 16 countries, they demonstrated that national factors interfere with measures of accounting information relevance (measured by the ability of profits and equity values to explain returns). Referring to the national factors that the author considered, those in which the economy is oriented by banks stand out in relation to those oriented by the market. The authors also noted private involvement in standard setting, continental versus American/ British model, legal regime and amount spent on auditing.

Similarly, a survey based on a sample of 34 countries between 1985 and 1998 by Bhattacharya et al. (2003) evaluated some measures of "earnings opacity" (the lack of transparency of earnings, captured by income smoothing, measures of earnings aggressiveness or avoiding loss reporting). These authors aimed to discover how such elements interfered in the characteristics of their stock markets. According to the evidences observed in the research, it was possible to detect an increase in the cost of capital and a reduction in the number of market transactions.

Hope (2003) investigated the relationship between the accuracy of financial analysts' forecasts, the disclosure level of the companies' annual reporting, and the degree of compliance with accounting standards in 23 countries. According to his findings, the level of evidence positively influences the degree of accuracy in the predictions. This result suggests that the financial statements present informational content to analysts. At the country level, however, the author found that a strong level of enforcement is associated with greater accuracy in the forecasts. This consistently highlights the view that enforcement encourages managers to follow prescribed accounting standards, which reduces analysts' uncertainty about future earnings.

From this perspective, Lang, Raedy, and Yetman (2003) investigated how foreign companies' listing in the US stock exchange would interfere in how accounting is reported in local markets. They found that listed firms differ in terms of the properties of time series of profits and accruals and the degree of association between accounting data and stock price. In this case, they confirmed that the companies listed on the US stock market are less aggressive in terms of earnings management. The authors also suggest that the accounting data they report are more conservative, incorporate negative news more timely and are more closely associated with stock prices.

From a different perspective, Ball, Robin \& Sadka (2005) examined the importance of stock markets and the debt securities market in timely recognition of losses (conservatism). The tests performed related the timely recognition of gains or losses to the relative size of the stock markets and of the countries' debts to the gross national product. The results showed that there is a positive relationship between the measures of loss recognition and the size of the debt market.

Hail and Leuz (2006) examined international differences in firms' cost of capital in 40 countries. They went on to investigate how the effectiveness of legal institutions and the regulation of the stock market is systematically related to differences among countries in the cost of capital. The results lead to the conclusion that firms with higher requirements for disclosure, stronger regulation and stricter enforcement mechanisms have lower cost of capital. These conclusions were derived from a comprehensive sensory analysis, which looked at the elements that tend to influence a country's long-term growth. Another noteworthy finding in the authors' work concerns the effects of the cost of capital on strong legal institutions, which becomes substantially smaller as the market becomes more integrated. Results by Papaioannou (2009) can be considered complementary to these findings, since the author detected that institutional quality was considered a key determinant in the international financial flow of banks across 50 countries. Their findings 
also suggest that variables such as weak protection of owners' rights, legal inefficiencies and high risk of expropriation are key factors in inhibiting the growth of foreign capital in banks.

A similar research strategy was employed by Lee and $\mathrm{Ng}$ (2009), but extensive to the firm level in 44 countries. These authors have succeeded in demonstrating that companies with more corruption (measured by corruption rates) deal with significantly lower market multiples. In this case, it should be mentioned that the magnitude of the report was significant, in economic as well as statistical terms. Under these conditions, the authors were able to demonstrate that corruption impacts value through the reduction of future cash flows, more directly captured by firms' profit forecasts.

Lang, Lins, and Maffett (2012), in a similar analysis, examined the association between transparency and stock market liquidity and the valuation process, analyzing how this link varied according to firm characteristics and the economic environment. Among their findings, we highlight that the incidence of lower transaction costs and greater liquidity for firms with a higher level of transparency has been connected to countries' institutional environment. Lang et al. (2012) comment that part of this phenomenon can be attributed to institutional investors' financing constraints.

The chain of findings indicates that these differences can be consistently explained by factors peculiar to each country, specifically regarding transparency, governance and companyspecific factors, such as liquidity. In addition to this perspective, substantial literature has been constructed to detect systematic differences in the content and timing of financial reporting (Ball, Kothari \& Robin, 2000; Ball, Robin \& Sadka, 2005; Bushman \& Piotroski, 2003; Hope, 2003; Lang, Raedy \& Yetman, 2003).

\subsection{Legal origins}

La Porta et al. (1997, 1998) began from the proposition emphasized by Shleifer and Vishny (1997) that the legal protection of investors that are external to the firm limits the extent of these investors' expropriation by agents that are internal to the firm, thus promoting the firm's development. According to these authors, the laws and regulations that protect stockholders vary systematically between traditions and origins, in which laws in common law countries (originating from British law) protect the external investors more than laws in civil law countries (originating from Roman law). Figure 1 shows the division of countries according to the classification by La Porta et al. (2008).

La Porta et al. (2008) argue that the common law and civil law tradition was transplanted through conquest and colonization. They also defend that human capital and legal ideologies were transplanted under these conditions. Despite much legal evolution, the fundamental strategies and assumptions of each legal system have survived and exert substantial influence on economic outcomes. The authors identify two major secular traditions - common law and civil law. Besides these, they also refer to a series of subtractions - French, Germanic, socialist and Scandinavian - within civil law. However, it should be mentioned though that, in general, one particular tradition is dominant in each country.

The work by La Porta et al. (1998) concentrated on analyzing the legal standards in protection of shareholders and creditors, the origins of these standards and the quality of enforcement, considering companies operating in 49 countries. Among the main findings, the authors reported: a) common law countries stood out for maintaining a more intense level of legal protection to investors; B) civil law countries of French origin positioned at the lower end of the scale; and c) Germanic and Scandinavian countries presented an intermediate situation in this dimension. In addition, the findings by $\mathrm{La}$ Porta (1999) indicate that the ownership structure of the companies in their sample showed to be more concentrated in the case of firms located in countries with lower level of stockholder protection, highlighting family-group or State control. 


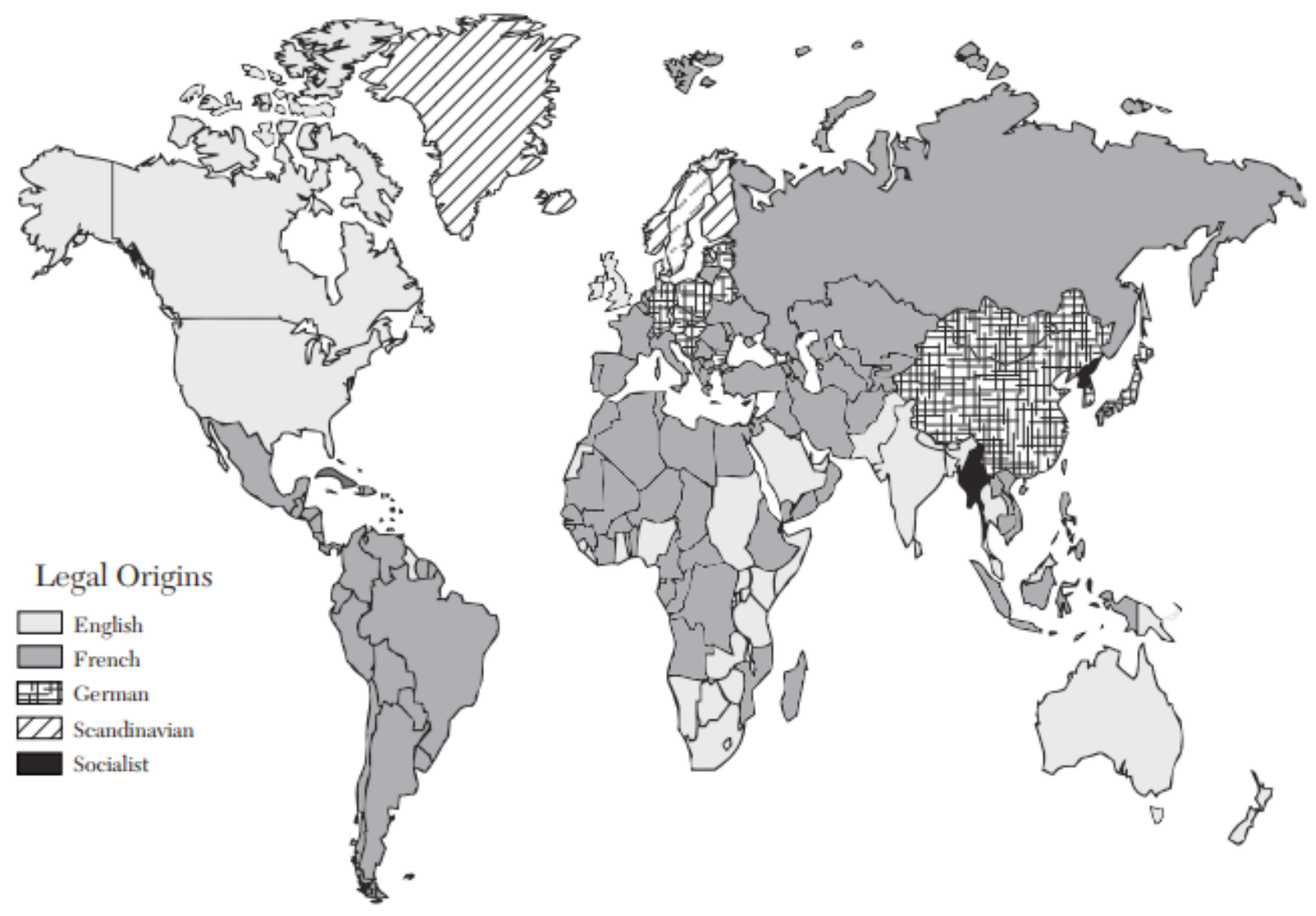

Figure 1. Countries' legal system

From "The economic consequences of legal origins" de R. La Porta, F. Lopez-de-Silanes, and A. Shleifer, 2008, The economic consequences of legal origins, p. 289.

With respect to differences in legal systems, the study by Demirgüç-Kunt and Maksimovic (1998) focused on how the differences between legal and financial systems affect the firm's use of external financing. The study showed that countries where the legal system has a high efficiency rating join a large proportion of firms using long-term external financing. This increase in the use of external financing partially occurs because firms established in countries with institutions with a good level of financing have low profitability rates.

In the work of Ball et al. (2000), international differences were evaluated concerning the way in which accounting earnings incorporate economic earnings (change in the market value) over time. According to these authors, the difference of conservatism in the classification of countries in common-law and code-law influences the demand for incentives, acting unfavorably to the practice of timely reporting. Given that in countries classified as code-law there is a very strong connection between accounting earnings and the payment of taxes, it is to be expected that these countries' accounting tends to be less timely, particularly with regard to the incorporation of economic losses. Ball et al. (2000) add that the level of regulation and taxation is a relevant element to explain differences from common law countries.

Bushman, Piotrosk, and Smith (2004) and Jaggi and Low (2000) examined how the accounting systems of firms' home countries interfere in the elaboration of different transparency measures. More specifically, they examined how the legal system of firms' country of origin can 
be associated with their financial disclosure level. These authors have demonstrated that the firms of common law countries are associated with greater financial disclosure when compared to the firms of code law countries. In addition, Jaggi and Low (2000) identified that, especially in common law countries, cultural values were intervening variables that contributed significantly to the level of disclosure.

To Bushman et al. (2004), a country's transparency results from a multifaceted system. In this understanding, its components collectively produce, collect, validate, and disseminate information. In short, to analyze the elements related to the countries' informational environment, they formatted two main factors. The first of these is inherent to financial transparency and related mainly to the country's economic policy, which captured the intensity and timing of financial disclosure, its interpretation and dissemination through the media. On the other hand, the characteristics and transparency regarding the governance structure appear to be essentially related to the countries' legal/judicial systems.

Analysis carried out by Bushman and Piotroski (2006) can be considered complementary to these findings. This is because these authors have evaluated the influence exerted on accounting from the legal/judicial system, the stock market regulations and the economic policy. The creation of incentives that influence the behavior of executives, investors, regulators and other participants in the market framed the scenario they studied. The evidence raised by Bushman and Piotroski (2006) shows consistent differences in the level of conservatism, according to the countries' legal and political institutions (legal origins, legal status, legal enforcement, expropriation risk and state ownership).

\subsection{Adoption of international standards}

Studies focused on the relevance of accounting information were performed. Barth et al. (2008) presented evidences that the adoption of the firm presents the quality of financial reporting. According to the authors, the application of IAS reflects the combined effects of financial reporting system characteristics, including standards, their interpretations, enforcement and recurrent litigation risk. The authors have shown that, for the 21 countries analyzed, there was generally less earnings management, greater timely recognition and greater informational content of accounting values than in a sample made up of firms that apply non-international (and also non-US) standards. They found evidence of improved accounting in the pre- and post-adoption period. It could not be assumed, however, that the changes came from international standards or changes in the economic incentive environment, although variables were included to control for the second effect.

Christensen, Lee, and Walker (2007) and Horton and Serafeim (2010) reported that earnings reconciliations could enhance the price relevance when compared to local UK standards. For the seven countries they examined from common law countries and seven from code law countries, Capkun Cazavan-Jeny, Jeanjean, and Weiss (2008) reported incremental tests that once again ensured that financial statements transmit relevant information in relation to local standards. Finally, Wang (2008) noted that differences in reconciliations in net income are positively related to returns, a result that is again consistent with the incremental power of IFRS standards.

Daske, Hail, Leuz, and Verdi (2008) examined the impact of the mandatory adoption of international standards in several countries, including some in the European Union. They reported that, on the occasion of the first mandatory adoption, companies that did so exhibited a modest increase in the cost of capital. Daske et al. (2008) found that the adoption of international standards resulted in market benefits only in countries where firms were granted incentives to increase their transparency and especially when the degree of enforcement is high. Moreover, effects have been more 
pronounced when local standards differ more from international ones.

Clarkson, Hanna, Richardson, and Thompson (2011) investigated the impact of the adoption of international standards in Europe and Australia and the relevance of equity value and profits to asset valuation. The results indicated that there were changes in both common law and code law countries, also suggesting that the distribution of earnings measures became more similar among countries subject to the two instruments.

As a premise, we accept the proposition that accounting data may be more informative if the firm follows international standards, particularly if the firm comes from a country with low quality of local accounting standards. Daske, Hail, Leuz, and Verdi (2013), however, point out that it is relatively simple for companies to adopt an IFRS label, but without making substantial changes, with any actual economic effect.

\section{Methodological procedures}

In this chapter, we describe the methodological procedures that were adopted in this study, the collected sample, and the operational definitions of the research variables.
Furthermore, we present the tests performed to investigate the research hypotheses.

\section{I Delimitation of the research sample}

The company's financial data was extracted from the S\&P Capital IQ database, a financial platform originally designed to respond to the needs of the community of investment analysts, but later extended to the members of the academy (Hines, 2012). The sample consisted of publicly traded companies registered on the capital market under the classification "emerging", according to the criterion by Standard \& Poor's (2013). It should further be mentioned that the time period the research covered ranged from 2004 to 2013. Hence, countries with recent reclassifications were excluded from the sample.

To compose the sample, only companies with complete data for all variables studied across all years were considered. Thus, the research sample consisted of 60,121 observations. The sample included publicly traded companies registered on the capital market under the classification "emerging", according to the criterion by Standard \& Poor's (2013). The sample analyzed consisted of 60,121 observations, as presented in Table 1.

Table 1

\section{Sample composition}

\begin{tabular}{|c|c|c|c|c|c|c|c|}
\hline País & $\begin{array}{c}\text { Final } \\
\text { sample }\end{array}$ & Country & $\begin{array}{c}\text { Final } \\
\text { sample }\end{array}$ & Country & $\begin{array}{c}\text { Final } \\
\text { sample }\end{array}$ & Country & $\begin{array}{c}\text { Final } \\
\text { sample }\end{array}$ \\
\hline Brazil & 1,419 & Egypt & 492 & Mexico & 619 & Russia & 293 \\
\hline Chile & 963 & Hungary & 110 & Morocco & 364 & South Africa & 1,406 \\
\hline China & 12,693 & India & 16,889 & Peru & 486 & Taiwan & 9,719 \\
\hline Colombia & 220 & Indonesia & 2,074 & Philippines & 1,107 & Thailand & 3,227 \\
\hline Czech Republic & 49 & Malaysia & 5,360 & Poland & 1,115 & Turkey & 1,516 \\
\hline Total & & & & & & & 60,121 \\
\hline
\end{tabular}

\subsection{Non-parametric tests}

The incompatibility of the correlation analysis for the use of categorical variables required the use of tests of comparison of means. For the determination of the correct test statistic, parametric or non-parametric, some assumptions were evaluated, among them the normality of the data. When the null hypothesis of normal data distribution was rejected, non-parametric tests were performed. 
In order to compare the indicators among the group of countries while taking into account their institutional characteristics, the MannWhitney test and the Kruskal-Wallis test were performed. The Mann-Whitney test, used for the specific existence of two categories, has the same purpose as student's t-test for independent samples: to compare if two independent samples come from two populations with equal means. According to Favero and Belfiore (2017), the test is an interesting alternative to the parametric test for equality of means (t-test), since MannWhitney does not demand any hypotheses about population distributions and their variances, based on a sum of ranks.

Stevenson (2001) states that, when country-year observations were grouped into more than two groups, the non-parametric Kruskal-Wallis test was used. As a non-parametric alternative to one-way ANOVA, the test is used to evaluate whether three or more independent samples were extracted from populations with equal means. The Kruskal-Wallis test, as well as the Mann-Whitney test, does not require normal distributions, nor does it depend on the homogeneous variance prerequisite.

\subsection{Analyzed variables}

The inclusion of variables referring to the political/legal structure was considered, aiming to capture the extent of legal enforcement, the stockholders' rights and the legal origins (common law versus code law). In this context, variables related to the financial reporting regimen are considered, aiming to capture the difference among countries related to the extent of earnings aggressiveness, the trend to avoid losses, income smoothing and the use of international accounting standards. Among the five variables used to capture national aspects of the companies' financial reporting, three are inspired by the empirical study by Bhattacharya et al. (2003), with solid theoretical foundations in accounting research.

\subsection{Earnings aggressiveness}

Bhattacharya et al. (2003) define "earnings aggressiveness" as the trend to postpone the recognition of losses and anticipate the recognition of gains. These authors' argument is based on the fact that the opposite of aggressiveness is conservatism. The author specifically argues that conservatism a) in view of managers' preference for economic gains tends to signal more plausible information; b) economic losses more strongly affect the creditors; and c) the timely incorporation of the economic losses is a relevant governance factor, offering rapid feedback on bad decisions and investments and decisions and strategies the managers may not want to disseminate. Despite the existence of arguments that conservative accounting prevents the rapid transmission of good news, it is reasonable to expect that, on average, managers are encouraged to expand more than underestimate the earnings. Therefore, the authors argue that aggressive earnings are expected to be substantially more opaque, exhibiting biased and too optimistic reports by managers.

The trend to postpone the recognition of losses and anticipate the recognition of gains implies that, if the accomplishment of the cash flow does not change, the accruals are expected that increase with the earnings aggressiveness. The measure will be calculated by the median quotient between the total accruals and the total lagged assets of country $i$ in year $t$ (the use of the median minimize the influence of extreme values). The higher the median of the accruals, the greater the earnings aggressiveness (Ahmed, Billings, Morton \& Stanford-Harris, 2002; Bhattacharya et al., 2003; Givoly \& Hayn, 2000).

To calculate the accruals in a way consistent with the background literature, which predominates in this study area (e.g., Sloan, 1996; Takamatsu \& Fávero, 2013), they were calculated based on information from the Balance Sheet and the Income Statement, based on the following formula: 


$$
A c c=\frac{\left(\Delta C A_{t-(t-1)}-\Delta C x_{t-(t-1)}\right)-\left(\Delta C L_{t-(t-1)}-\Delta S T D_{t-(t-1)}-\Delta T P_{t-(t-1)}\right)-D e p}{\frac{1}{2} X\left(\mathrm{TA}_{\mathrm{t}-1}+\mathrm{TA}_{t}\right)}
$$

Where:

$\triangle A C=$ change in current assets

$\triangle C x=$ change in cash/cash equivalents

$\triangle C L=$ change in current liabilities

$\Delta s t=$ change in debt included in current liabilities

$\triangle T P=$ change in income taxes payable

$D e p=$ depreciation and amortization expense

$\mathrm{AT}_{\mathrm{t}-1}=$ Total lagged assets

$\mathrm{AT}_{\mathrm{t}}=$ Total current assets

\subsubsection{Aversion to losses}

The second measure of earnings opacity is loss-aversion behavior, which refers to companies' efforts to avoid reporting negative profits. DeGeorge, Cazavan-Jeny, Jeanjean, and Weiss (1999) presented evidence suggesting the following hierarchies among profit holders: a) avoid negative profits; B) report an increase in quarterly profits; and c) achieve the analysts' forecasted earnings. Thus, incentives to report positive earnings are observed. This behavior makes the relationship between future economic earnings obscure, increasing the opacity of earnings.

Bhattacharya et al. (2003) compute the loss aversion measure as follows: low-profit firms were defined as those that showed a net profit for total assets between $0 \%$ and 1\%. Likewise, firms with a low injury level were defined as those that showed a loss for total assets between $0 \%$ and $-1 \%$. Thus, the index is calculated by the difference between the number of firms with small positive profits and the number of firms with losses, by the sum of the two company categories. The higher the index in country $i$ and year $t$, the greater companies' trend towards managing results to avoid reporting losses.

\subsubsection{Income smoothing}

This variable is also based on the research developed by Bhattacharya et al. (2003). If accounting income is artificially smoothed, it fails to demonstrate the true change in firm performance by reducing the informational capacity of reported accounting figures, thereby increasing the opacity of profits. It should be emphasized that this view is not a consensus in the literature. Authors such as Tucker and Zarowin (2006) argue that income smoothing can enhance the informativeness of figures if managers use discretion to communicate their assessment of future earnings. The smoothing of profits will be calculated by the cross-sectional correlation between changes in accruals and changes in cash flows, divided by the total assets lagged. The more negative this correlation, the greater the level of profit smoothing in country $i$ in year $t$.

\subsubsection{Use of international standards}

The variable "Use of International Accounting Standards" consists of a dichotomous variable in which, even if the country uses national standards with some modifications to local conditions, it will be classified in the group of countries that do not fully adopt the international standards.

As a presupposition, the proposition is accepted that accounting data may be more informative if the firm follows international standards, particularly if the firm comes from a country with low-quality local accounting standards. Daske et al. (2013), however, point out that it is relatively simple for companies to 
voluntarily adopt an IFRS label, but without making substantive changes with any actual economic effect. Similarly, Daske et al. (2008) found that the IFRS resulted in market benefits only in countries where firms were given incentives to increase their transparency and especially when the level of enforcement is high.

\subsubsection{Legal origins}

Based on the classification of La Porta et al. (2008), the countries were classified based on the origins of the legal systems, that is: common law, French code law; German code law; Scandinavian code law and socialist code law. This classification departs from the premise that external investors' legal protection can vary between traditions and legal origins. According to La Porta et al. (1997, 1998), common law countries (originating in British law) protect the external investors more than civil laws (originating in Roman laws). Hence, this type of distinction can interfere in accounting figures' informational capacity.

\section{Presentation and analysis of results}

Results are analyzed and discussed in this chapter. Initially, the general characteristics of the sample are presented, as well as the descriptive statistics, followed by the assessment of the previously defined research questions.

\section{I Descriptive statistics and characteristics of the variables}

The general characteristics of the sample are descriptively established based on the general features that outline the countries in the sample. Thus, Table 1 presents a summary of the characteristics related to the informational level of the nations the sample companies are inserted in. It is observed that, according to the classification by La Porta et al. (2008), countries can be classified based on the legal origins of the legal systems, namely: common law; French code law; German code; Scandinavian code; and socialist code. A closer look at the study sample reveals the non-existence of countries with a Scandinavian code and socialist code.

Among the countries shown in Table 1, some, such as China, still do not fully adopt the international accounting standards. This is so because, despite the fact that Chinese companies coexist with their accounting standards already substantially converged towards IFRS, their translation sometimes does not correspond directly to the standard issued by the IASB. In other words, the standards of this board are rewritten in a simplified format to facilitate the understanding of the Chinese, not always respecting the spirit of the law. In a similar situation, India allows its companies to present their results in accordance with both local principles and international standards. Companies have more commonly prepared their statements according to Indian standards though. In both cases, countries were classified as "non convergent" to the international standards. This is so because a dichotomous variable was used to allocate countries in the group that adopts international standards, although not including possible partial adoptions that may occur.

Concerning Table 2, there are cases such as in Brazil where, through the publication of Law 11.638/07 and Law 11.941/09, the companies listed on BM\&FBovespa are now required to prepare their financial statements in accordance with the international standards. Therefore, the Accounting Pronouncements Committee has assumed the role of guardian of professional practices in Brazil, so that its content is equivalent to those issued by the IASB. In this case, as from the moment of the transition, the dummy referring to the use of international standards became equal to 1 , such as in the case of Chile, Malaysia, Mexico, Peru, Russia, Taiwan and Turkey. 
Table 2

Summary of main measures referring to the country's informational environment

\begin{tabular}{|c|c|c|c|c|c|c|c|}
\hline Country & $\begin{array}{c}\text { Earnings } \\
\text { Aggressiveness }\end{array}$ & $\begin{array}{c}\text { Income } \\
\text { Smoothing }\end{array}$ & $\begin{array}{c}\text { Loss } \\
\text { Aversion }\end{array}$ & English & French & German & IFRS \\
\hline Brazil & $-0.268 \%$ & 0.460 & 0.333 & No & Yes & No & Transition \\
\hline Chile & $-0.785 \%$ & 0.157 & 0.182 & No & Yes & No & Transition \\
\hline China & $2.660 \%$ & 0.822 & 0.853 & No & No & Yes & No \\
\hline Colombia & $-1.586 \%$ & 0.577 & 0.600 & No & Yes & No & No \\
\hline Czech Republic & $-4.895 \%$ & 0.147 & 1.000 & No & No & Yes & Yes \\
\hline Egypt & $-1.781 \%$ & 0.233 & 0.750 & No & Yes & No & No \\
\hline Hungary & $-3.981 \%$ & -0.120 & 0.000 & No & No & Yes & Yes \\
\hline India & $-1.738 \%$ & 0.676 & 0.419 & Yes & No & No & No \\
\hline Indonesia & $0.725 \%$ & 0.658 & 0.727 & No & Yes & No & No \\
\hline Malaysia & $0.636 \%$ & 0.331 & 0.512 & Yes & No & No & Transition \\
\hline Mexico & $-0.657 \%$ & 0.165 & 0.571 & No & Yes & No & Transition \\
\hline Morocco & $-0.747 \%$ & -0.065 & 1.000 & No & Yes & No & No \\
\hline Peru & $-0.308 \%$ & 0.433 & 0.600 & No & Yes & No & Transition \\
\hline Philippines & $-0.306 \%$ & 0.503 & 0.214 & No & Yes & No & Yes \\
\hline Poland & $-0.195 \%$ & 0.203 & 0.563 & No & No & Yes & Yes \\
\hline Russia & $-1.884 \%$ & 0.382 & 0.632 & No & Yes & No & Transition \\
\hline South Africa & $-0.586 \%$ & 0.500 & 0.529 & Yes & No & No & Yes \\
\hline Taiwan & $0.572 \%$ & 0.122 & 0.604 & No & No & Yes & Transition \\
\hline Thailand & $0.882 \%$ & 0.929 & 0.458 & Yes & No & No & No \\
\hline Turkey & $0.860 \%$ & 0.185 & 0.455 & No & Yes & No & Transition \\
\hline
\end{tabular}

* Medians of earnings opacity measures over the years in the sample.

Also in Table 2, the median of each of the gross measures of earnings opacity variables is shown, in each country in the sample. It is observed that the column of earnings aggressiveness presents the median of the accruals divided by the total of lagged assets for the countries in the sample. The income smoothing column shows the relationship between accruals and cash flow changes. Some degree of this smoothing is a natural consequence of the accounting process. The stronger this level, however, the more likely this procedure is to obscure the variability of the underlying economic process and the greater the opacity of profits. Given that a negative correlation would denote greater smoothing, the inverse of this variable was calculated to aid in the reading of the variable. Thus, the higher its level, the greater the smoothing.
The measures of income smoothing, earnings aggressiveness and loss aversion sought to capture similar effects (opacity) through different calculations. Thus, we performed a correlation analysis of the variables in Table 3.

Table 3

\section{Correlation among opacity measures}

\begin{tabular}{lccc}
\hline & $\begin{array}{c}\text { Income } \\
\text { Smoothing }\end{array}$ & $\begin{array}{c}\text { Earnings } \\
\text { Aggressiveness }\end{array}$ & $\begin{array}{c}\text { Loss } \\
\text { Aversion }\end{array}$ \\
\hline $\begin{array}{l}\text { Income } \\
\text { Smoothing }\end{array}$ & 1 & & \\
$\begin{array}{l}\text { Earnings } \\
\text { Aggressiveness }\end{array}$ & $0.1925^{* * *}$ & 1 & \\
Loss Aversion & $0.2284^{* * *}$ & $0.4098^{* * *}$ & 1 \\
\hline
\end{tabular}

* significant at $10 \%$ ** significant at $5 \%$ *** significant at $1 \%$ 
Table 3 shows the correlation between each of the three measures of opacity. Their absolute values range between 0.1925 and 0.4095 , indicating that, although there is some relationship between the three variables of earnings opacity and even though they exhibit a common component, related to the level of opacity of the countries' accounting informational environment, each indicator expresses its own information. By reading Table 3, it can also be verified that there is a positive relationship between earnings aggressiveness and income smoothing, which shows that higher aggressiveness of accruals results in smoother earnings (with a strong and negative correlation between accruals and changes in cash flow). Also, the more averse companies are to losses, the more they will soften their results and the more aggressive their behavior with regard to the reporting of earnings will be.

\subsection{Hypothesis test}

To assess the relationship among the variables that are inherent to the adoption of international standards and legal origins, data on the test of means exhibited in Tables 4, 5 and 6 are initially explored. This is because the adoption or not of the international accounting standards and the legal origins of the countries' accounting standards are equally qualitative variables and their inclusion in the correlation matrix could entail mistaken conclusions. Thus, for the test of means, first, the normality test of the earnings opacity variables was applied.

Table 4

\section{Normality test of the opacity measure}

\begin{tabular}{lccccc}
\hline Variable & Obs & W' & V' & Z & Prob $>\mathbf{z}$ \\
\hline Earnings Aggressiveness & 160 & 0.52891 & 63.459 & 8.458 & 0.00001 \\
Income Smoothing & 160 & 0.96338 & 4.933 & 3.252 & 0.00057 \\
Loss Aversion & 155 & 0.93662 & 8.312 & 4.307 & 0.00001 \\
\hline
\end{tabular}

Table 4 explains the rejection of the null hypothesis of normality of all three variables of earnings opacity. This scenario makes it impossible to apply parametric tests, which require assumptions about the distribution of sample data. Therefore, the non-parametric tests of Mann-Whitney and Kruskal-Wallis (Fávero \& Belfiore, 2017) were applied. The first is to assess the relationship between the earnings opacity and the adoption of IFRS. In turn, the KruskalWallis test is used to evaluate the influence of legal origins, since there are more than two categories of origins. Therefore, Tables 5 and 6 show the level of earnings opacity, taking into account the variables on the countries' institutional environment. 
Table 5

Mann-Whitney test: Relationship between earnings opacity and the adoption of international standards

\begin{tabular}{|c|c|c|c|c|}
\hline Variable & & Adopted IAS & $\begin{array}{l}\text { Not adopted } \\
\text { IAS } \\
\end{array}$ & Combined \\
\hline \multirow{6}{*}{ Earnings Aggressiveness } & Obs & 96 & 64 & 160 \\
\hline & Rank sum & 8,677 & 4,203 & 12,880 \\
\hline & Expected & 7,728 & 5,152 & 12,880 \\
\hline & \multirow{3}{*}{\multicolumn{4}{|c|}{$\begin{array}{c}\text { Adjusted Variance }=82,432 \\
z=3.305 \\
\text { Prob }>|z|=0.0009\end{array}$}} \\
\hline & & & & \\
\hline & & & & \\
\hline \multirow{6}{*}{ Income Smoothing } & Obs & 96 & 7,730 & 7,728 \\
\hline & Rank sum & 64 & 5,150 & 5,152 \\
\hline & Expected & 160 & 12,880 & 12,880 \\
\hline & \multirow{3}{*}{\multicolumn{4}{|c|}{$\begin{array}{c}\text { Adjusted Variance }=82.432 \\
z=0.007 \\
\text { Prob }>|z|=0.9944\end{array}$}} \\
\hline & & & & \\
\hline & & & & \\
\hline \multirow{6}{*}{ Loss Aversion } & Obs & 96 & 59 & 155 \\
\hline & Rank sum & $8,404.5$ & $3.685,5$ & 12,090 \\
\hline & Expected & 7,488 & 4602 & 12,090 \\
\hline & \multicolumn{4}{|c|}{ Adjusted Variance $=73,493.43$} \\
\hline & \multicolumn{4}{|c|}{$\mathrm{z}=3.381$} \\
\hline & \multicolumn{4}{|c|}{ Prob $>|z|=0.0007$} \\
\hline
\end{tabular}

We observed that the use of international standards had a positive influence on two of the three measures of earnings opacity. This suggests that the use of international standards helps to reduce the earnings aggressiveness and the level of loss aversion. This conclusion is different from those advocated by Ball, Robin, and Wu (2003) and Bhattacharya et al. (2003). Thus, even if the usage degree of international standards is difficult to measure accurately, there was a link between using international standards and reducing the earnings opacity.

Table 6

Kruskal-Wallis test: Relationship between earnings opacity level and legal origins

\begin{tabular}{|c|c|c|c|c|}
\hline Variable & & English & French & German \\
\hline \multirow{4}{*}{ Earnings Aggressiveness } & Obs & 32 & 88 & 40 \\
\hline & Rank sum & 2,879 & 6,897 & 3,104 \\
\hline & \multirow{2}{*}{\multicolumn{4}{|c|}{$\begin{array}{c}\text { Chi-Square }=1.678 \mathrm{com} 2 \mathrm{~d} . f \\
\text { P-Value }=0.4321\end{array}$}} \\
\hline & & & & \\
\hline \multirow{4}{*}{ Income Smoothing } & Obs & 32 & 88 & 40 \\
\hline & Rank sum & 2,967 & 6,675 & 3,238 \\
\hline & \multicolumn{4}{|c|}{ Chi-Square $=3.115$ com 2 d.f., } \\
\hline & \multicolumn{4}{|c|}{ P-Value $=0.2107$} \\
\hline \multirow{4}{*}{ Loss Aversion } & Obs & 32 & 88 & 35 \\
\hline & Rank sum & $1,985.5$ & 6,985 & $3,119.5$ \\
\hline & \multicolumn{4}{|c|}{ Chi-Square $=6.287$ com 2 d.f., } \\
\hline & \multicolumn{4}{|c|}{ P-Value $=0.0431$} \\
\hline
\end{tabular}


It is interesting to note that only the measure of loss aversion presented a statistically significant difference, even if the sum of the ranks referring to legal origin "French code" has resulted in a higher value. The lack of significance can be explained by the small number of observations, since the units under analysis were not companies, but countries/year. Even if the relationship was not significant, the sum of ranks of the three earnings opacity measures was greater for the French code.

\section{Final considerations and recommendations}

The objective of this study was to evaluate the relationship between characteristics of the informational environment of accounting and the opacity levels of information accounting produces. Thus, the empirical arguments and evidences were first presented, relating the characteristics of the accounting figures disclosed by the firm and how these characteristics can be influenced by variables related to country-specific factors. In particular, according to international literature, superior quality and a lower management level have been detected in common law countries and countries that have adopted international accounting standards.

The review carried out by this thesis reveals that emerging markets tend to have lower levels of legal enforcement, structural stability, and a lower level of information available in relation to publicly-traded companies. In this kind of environment, a lesser explanatory power is expected from indicators that use accounting information as an input (Fatma \& Abdelwahed, 2010). Even when participating in the same cluster though, this category covers countries with mutually very different characteristics, which demonstrates the convenience of controlling the informational characteristics of the country.

In the analysis of the results, the fact that informational environment measures were correlated was evident, suggesting that the proxies of opacity, even with different components, carried the same information. It was also observed that the earnings opacity was lower in countries that had already switched to the international standards in the period under analysis. Also in this scope, a higher level of income smoothing was detected in countries whose legal origins go back to the French common law.

Recently, the transition to international accounting standards has been extensively explored in several scenarios in an attempt to employ high-quality reporting standards. Thus, the informational capacity of reports related to company-specific information is enhanced. Regulators responsible for setting standards therefore lack the elements to better understand users' needs and how regulatory changes alter their perspectives. Thus, this article contributes to strengthen this dimension by providing evidence that the transition has fulfilled its role since, in countries where the international standards are applied, the opacity in two of the three measures used has been reduced.

Like the adoption of high-level accounting standards influences the informational capacity of accounting, the quality of accounting information also depends on the incentives of managers and auditors. Despite the non-significance in two of the three measures evaluated, the level of loss aversion for companies located in countries of common law origins was lower than that of countries of code law origins, as expected.

On the whole, however, the analyses carried out present important limitations that need to be considered when interpreting results. This is because all proxies exhibit measuring errors, which can impact the analysis. Another point that can be raised concerns the selected sample: even though uniformly called "emergent", the group was composed of heterogeneous and geographically dispersed countries with distinct levels of development (such as Chile, China, Poland, and Taiwan). Despite the attempts to control all factors suggested in the background literature, theoretical and empirical limitations would prevent full awareness of all important 
influences, making it impossible to exhaust all control possibilities.

As a suggestion for future research, it is important to emphasize the importance of additional variables to capture the opacity of accounting information, both at company level and at the country level. The level of earnings opacity in this study was evaluated considering the informational environment at the country level. Other studies can explore this element based on a series of alternative measures, and also intervene in the earnings opacity at the individual level, such as the degree of quality of the accounting information disclosed at the company level. That is so is because this is an element that portrays the reliability of the reported information. In addition, it also permits the investigation of traces of possible earnings management.

It is also relevant to invest in the detection of countless factors related to the institution and the informational environment that can affect the informational capacity of the accounting data. Thus, among the possibilities for expansion of this research, we highlight the inclusion of variables concerning companies' disclosure level in countries; and concerning the governance structure and auditing characteristics of each country.

Also, the possibility of conducting research that identifies how institutional factors interfere in the accounting disclosure differences among countries is highlighted. This study seeks behavioral patterns in accounting earnings that identify managers' intention to mask the results, based on opacity, international standards and legal origins. In other words, this study assesses the quality of financial reporting among countries, not in terms of the disclosure amount and pattern, but through statistical measures based on economic concepts. Nevertheless, it is of fundamental importance to detect which institutional factors interfere in the accounting disclosure, mainly voluntary, and how the market reacts to this disclosure. Thus, we identify the possibility of carrying out subsequent work that fits into the categories proposed by Verrecchia (2001) and critically discussed by Dye (2001) concerning the Theory of Accounting Disclosure. The taxonomy, consisting of three categories regarding accounting disclosure (disclosure based on association, discretion and efficiency) reveals the possibility of carrying out surveys that compare countries, assessing differences in the exogenous effects of disclosure, in the way companies exercise discretion in disclosure information and/or verify its relationship with company performance.

\section{References}

Ahmed, A. S., Billings, B. K., Morton, R. M., \& Stanford-Harris, M. (2002). The role of accounting conservatism in mitigating bondholder-shareholder conflicts over dividend policy and in reducing debt costs. The Accounting Review, 77(4), 867-890.

Ali, A., \& Hwang, L. S. (2000). Country-specific factors related to financial reporting and the value relevance of accounting data. Journal of Accounting Research, 38(1), 1-21.

Ball, R., Kothari, S. P., \& Robin, A. (2000). The effect of international institutional factors on properties of accounting earnings. Journal of Accounting and Economics, 29(1), 1-51.

Ball, R., Robin, A., \& Sadka, G. (2005). Is accounting conservatism due to debt or equity markets. Retrieved from http://www8.gsb.columbia.edu/ rtfiles/accounting/BALL_OBW_2005.pdf

Ball, R., Robin, A., \& Wu, J. S. (2003). Incentives versus standards: Properties of accounting income in four East Asian countries. Journal of Accounting and Economics, 36(1), 235-270.

Barth, M. E., Beaver, W. H., \& Landsman, W. R. (2001). The relevance of the value relevance literature for financial accounting standard setting: Another view. Journal of Accounting and Economics, 31(1), 77-104. 
Barth, M. E., Landsman, W. R., \& Lang, M. H. (2008). International accounting standards and accounting quality. Journal of Accounting Research, 46(3), 467-498.

Bhattacharya, U., Daouk, H., \& Welker, M. (2003). The world price of earnings opacity. The Accounting Review, 78(3), 641-678.

Bushman, R. M., \& Piotroski, J. D. (2006). Financial reporting incentives for conservative accounting: The influence of legal and political institutions. Journal of Accounting and Economics, 42(1), 107-148.

Bushman, R. M., Piotroski, J. D., \& Smith, A. J. (2004). What determines corporate transparency? Journal of Accounting Research, 42(2), 207-252.

Capkun, V., Cazavan-Jeny, A., Jeanjean, T., \& Weiss, L. A. (2008). Earnings management and value relevance during the mandatory transition from local GAAPs to IFRS in Europe. [Working Paper]. Retrieved from https://papers.ssrn.com/ sol3/papers.cfm?abstract_id $=1125716$

Christensen, H. B., Lee, E., \& Walker, M., (2007). Incentives or standards: What determines accounting quality changes around IFRS adoption? [Manchester Business School Working Paper, n. 523]. Retrieved from http:// mbsportal.bl.uk/secure/subjareas/accfinecon/ mubs/wp/140709WP523_07.pdf

Clarkson, P., Hanna, J. D., Richardson, G. D., \& Thompson, R. (2011). The impact of IFRS adoption on the value relevance of book value and earnings. Journal of Contemporary Accounting \& Economics, 7(1), 1-17.

Daske, H., Hail, L., Leuz, C., \& Verdi, R. (2008). Mandatory IFRS reporting around the world: Early evidence on the economic consequences. Journal of Accounting Research, 46(5), 1085-1142.

Daske, H., Hail, L., Leuz, C., \& Verdi, R. (2013). Adopting a label: Heterogeneity in the economic consequences around IAS/IFRS adoptions. Journal of Accounting Research, 51(3), 495-547.

Degeorge, F., Patel, J., \& Zeckhauser, R. (1999). Earnings management to exceed thresholds*. The Journal of Business, 72(1), 1-33.

Demirgüç-Kunt, A., \& Maksimovic, V. (1998). Law, finance, and firm growth. The Journal of Finance, 53(6), 2107-2137.

Dong, M., \& Stettler, A. (2011). Estimating firmlevel and country-level effects in cross-sectional analyses: An application of hierarchical modeling in corporate disclosure studies. The International Journal of Accounting, 46(3), 271-303.

Dye, R. A. (2001). An evaluation of "essays on disclosure" and the disclosure literature in accounting. Journal of Accounting and Economics, 32(1), 181-235.

Fatma, T., \& Abdelwahed, O. (2010). Earnings quality and cost of equity capital: Evidence from Tunisia. International Journal of Managerial and Financial Accounting, 2(2), 161-176.

Fávero, L. P., \& Belfiore, P. (2017). Manual de análise de dados: Estatística e modelagem multivariada com Excel, SPSS e Stata. Rio de Janeiro: Elsevier.

Foster, G., Kasznik, R., \& Sidhu, B. K. (2012). International equity valuation: The relative importance of country and industry factors versus company-specific financial reporting information. Accounting \& Finance, 52(3), 767-814.

French, K. R., \& Poterba, J. M. (1991). Were Japanese stock prices too high? Journal of Financial Economics, 29(2), 337-363.

Givoly, D., \& Hayn, C. (2000). The changing time-series properties of earnings, cash flows and accruals: Has financial reporting become more conservative? Journal of Accounting and Economics, 29(3), 287-320. 
Hail, L., \& Leuz, C. (2006). International differences in the cost of equity capital: Do legal institutions and securities regulation matter? Journal of Accounting Research, 44(3), 485-531.

Healy, P. M., \& Palepu, K. G. (2001). Information asymmetry, corporate disclosure, and the capital markets: A review of the empirical disclosure literature. Journal of Accounting and Economics, 31(1-3), p. 405-440.

Hines, T. M. (2012). S\&P Capital IQ. Journal of Business \& Finance Librarianship, 17(3), 279-279.

Hope, O. K. (2003). Disclosure practices, enforcement of accounting standards, and analysts' forecast accuracy: An international study. Journal of Accounting Research, 41(2), 235-272.

Horton, J., \& Serafeim, G. (2010). Market reaction and valuation of IFRS reconciliation adjustments: First evidence from UK. Review of Accounting Studies, 15(4), 725-751.

Jaggi, B., \& Low, P. Y. (2000). Impact of culture, market forces, and legal system on financial disclosures. The International Journal of Accounting, 35(4), 495-519.

Kothari, S. P. (2001). Capital markets research in accounting. Journal of Accounting and Economics, 31(1), 105-231.

Lang, M., Lins, K. V., \& Maffett, M. (2012). Transparency, liquidity, and valuation: International evidence on when transparency matters most. Journal of Accounting Research, 50(3), 729-774.

Lang, M., Raedy, J. S., \& Yetman, M. H. (2003). How representative are firms that are cross-listed in the united states? An analysis of accounting quality. Journal of Accounting Research, 41(2), 363-386.

La Porta, R., Lopez-de-Silanes, F., \& Shleifer, A. (1999). Corporate ownership around the world. The Journal of Finance, 54(2), 471-517.
La Porta, R., Lopez-de-Silanes, F., \& Shleifer, A. (2008). The economic consequences of legal origins'. Journal of Political Economy, 46(2), 285332.

La Porta, R., Lopez-de-Silanes, F., Shleifer, A., \& Vishny, R. W. (1997). Legal determinants of external finance. Journal of Finance, 52(3), 1131-1150.

La Porta, R., Lopez-de-Silanes, F., Shleifer, A., \& Vishny, R. W. (1998). Law and finance. Journal of Political Economy, 106(6), 1113-1155.

Lee, C. M. C., \& Ng, D. (2009). Corruption and international valuation: Does virtue pay? The Journal of Investing, 18(4), 23-41.

Leuz, C., Nanda, D., \& Wysocki, P. D. (2003). Earnings management and investor protection: an international comparison. Journal of Financial Economics, 69(3), 505-527.

Li, X., \& Sullivan, R. N. (2015). Investing in the asset growth anomaly across the globe. Journal of Investment Management, 13(4), 87-107.

Papaioannou, E. (2009). What drives international financial flows? Politics, institutions and other determinants. Journal of Development Economics, 88(2), 269-281.

Shleifer, A., \& Vishny, R. W. (1997). A survey of corporate governance. The Journal of Finance, 52(2), 737-783.

Sloan, R. (1996). Do stock prices fully reflect information in accruals and cash flows about future earnings? The Accounting Review, 71(3), 289-315.

Standard\&Poor's. (2013). S\&P Dow Jones Indices Announces: Country Classification Consultation Results. Retrieved from http:// www.spindices.com/documents/index-newsand-announcements/20131030-spdji-countryclassification-results.pdf 
Stevenson, W. J. (2001). Estatística aplicada à administração. São Paulo: Harbra.

Takamatsu, R. T., \& Fávero, L. P. L. (2013). Accruals, persistence of profits and stock returns in Brazilian public companies. Modern Economy, 4(1), 109-118.

Tucker, J. W., \& Zarowin, P. A. (2006). Does income smoothing improve earnings informativeness?. The Accounting Review, 81(1), 251-270.
Verrecchia, R. E. (2001). Essays on disclosure. Journal of Accounting and Economics, 32 (1-3), 97-180.

Wang, S. (2008). Timing equity issuance in response to mandatory accounting standards change in Australia and the European Union, Queen's University: Kingston, Ontario, Canada. Retrieved from: https://qspace.library.queensu.ca/bitstream/ handle/1974/1308/Wang_Shiheng_200807_ PhD.pdf; jsessionid=4BFCB1B900E4F2E8387 774A8BEBB4EDF? sequence $=1$

\section{Notes:}

1 Article derived from the doctoral thesis: «Indicadores contábeis, ambiente informacional de mercados emergentes e retorno das açốes " defended by Renata Turola Takamatsu in 2015, at the Faculty of Economics, Administration and Accounting, Universidade de São Paulo, under the orientation of Prof. Dr. Luiz Paulo Lopes Fávero.

\section{Supporting agencies:}

Pró-Reitoria de Pesquisa/UFMG

\section{About the authors:}

1. Renata Turola Takamatsu, Doctor of Philosophy in Accounting, Universidade de São Paulo, Brazil.

E-mail: rettakamatsu@gmail.com.

\section{ORCID}

0000-0002-0422-9895

2. Luiz Paulo Lopes Fávero, Doctor in Management, Universidade de São Paulo, Brazil.

E-mail: lpfavero@usp.br

ORCID

(iD) 0000-0001-8516-6701

\section{Contribution of each author:}

\begin{tabular}{lcc}
\hline Contribution & Renata Turola Takamatsu & Luiz Paulo Lopes Fávero \\
\hline $\begin{array}{l}\text { 1. Definition of research problem } \\
\text { 2. Development of hypotheses or research questions }\end{array}$ & $\sqrt{ }$ & $\sqrt{ }$ \\
(empirical studies) & $\sqrt{ }$ & $\sqrt{ }$ \\
3. Development of theoretical propositions (theoretical work) & $\sqrt{ }$ & $\sqrt{ }$ \\
4. Theoretical foundation / Literature review & $\sqrt{ }$ \\
5. Definition of methodological procedures & $\sqrt{ }$ & $\sqrt{ }$ \\
6. Data collection & $\sqrt{ }$ \\
7. Statistical analysis & $\sqrt{ }$ \\
8. Analysis and interpretation of data & $\sqrt{ }$ \\
9. Critical revision of the manuscript & $\sqrt{ }$ \\
10. Manuscript writing & $\sqrt{ }$ & $\sqrt{ }$ \\
\end{tabular}

